\title{
rRNA-targeted fluorescent in situ hybridization analysis of bacterial community structure in river water
}

\author{
Takehiko Kenzaka, Nobuyasu Yamaguchi, Katsuji Tani and Masao Nasu
}

Author for correspondence: Masao Nasu. Tel: +81 6879 8170. Fax: +81 68798174 .

e-mail: nasu@phs.osaka-u.ac.jp

Faculty of Pharmaceutical Sciences, Osaka University, 1-6 Yamada-oka, Suita, Osaka 565-0871, Japan
An improved in situ hybridization technique, HNPP-FISH, using 2-hydroxy-3naphthoic acid 2'-phenylanilide phosphate (HNPP) and Fast Red TR was applied to analyse the community structure of planktonic bacteria in river water. Oligonucleotide probes specific for the domain Bacteria (EUB338) and five bacterial groups [Flavobacterium-Cytophaga; Burkholderia-Pseudomonas (rRNA III)-authentic Alcaligenes; Vibrio-Aeromonas; Pseudomonas (rRNA I); the genus Acinetobacter] were used to investigate the bacterial community structure at two sites differing in organic carbon pollution level. At the eutrophic site, 54-68\% of all cells visualized by staining with DAPI (4;,6diamidino-2-phenylindole) could be detected with probe EUB338. In samples from the oligotrophic site, 39-45\% of the total cells hybridized with EUB338. At the eutrophic site, approximately $\mathbf{5 0} \%$ of the total cells were identified with the five group-specific probes; the bacterial community structure was dominated by the Flavobacterium-Cytophaga group and BurkholderiaPseudomonas (rRNA III)-authentic Alcaligenes group. At the oligotrophic site, only $26-38 \%$ of the total cells were identified with the five group-specific probes. The community structure at the oligotrophic site was similar to that at the eutrophic site, although the percentage of EUB338-detectable cells differed. No appreciable change was found in the community structure during the sampling period at either site. The improved HNPP-FISH technique should be a useful tool for the analysis of microbial community composition.

Keywords: rRNA-targeted oligonucleotide probes, fluorescent in situ hybridization, river, bacterial community structure

\section{INTRODUCTION}

Complex microbial communities carry out various environmental processes which are essential to maintain ecosystems, and the biogeochemical significance of bacteria is well established (Belser, 1979; Lovley, 1991; Wolin \& Miller, 1987). However, current knowledge of the structure and dynamics of natural microbial communities is rather limited, and the bacteria are still treated as a 'black box' in most ecological studies. Most studies on microbial community composition have been based on culture-dependent methods (Maeda, 1980;

Abbreviations: FISH, fluorescent in situ hybridization; HNPP, 2-hydroxy3-naphthoic acid 2'-phenylanilide phosphate.
Peele et al., 1981; Torsvik et al., 1990) despite the fact that many environmental bacteria cannot yet be cultivated by conventional laboratory techniques (Kogure et al., 1979; Olsen \& Bakken, 1987).

Various approaches have been used to identify microorganisms in natural samples without the requirement for laboratory cultivation. These include direct sequence analysis, sequencing of extracted $5 \mathrm{~S}$ rRNAs, and analysis of rRNA using reverse transcriptase or cloned rRNA genes obtained by amplification using PCR (Giovannoni et al., 1990; Stahl et al., 1985; Weisburg et al., 1991). A new technique, denaturing gradient gel electrophoresis has been developed which identifies sequence variations in a number of genes from complex microbial communities (Teske et al., 1996). However, the extraction, purification and amplification of nucleic acid from 
original samples is often selective and reductive (e.g. Suzuki \& Giovannoni, 1996).

Whole-cell hybridization techniques with fluorescently labelled, rRNA-targeted oligonucleotide probes allow not only detection of specific bacteria at the single-cell level but also determination of their abundance in complex communities (Amann et al., 1990; Hicks et al., 1992; Wallner et al., 1995). Investigations of this type on a natural aquatic system have been carried out by several researchers (Hicks et al., 1992; Glöckner et al., 1996; Ramsing et al., 1996). However, the application of in situ hybridization to the oligotrophic environment remains limited (Alfreider et al., 1996). This is primarily because the copy number of rRNA-binding sites in naturally occurring bacteria is much lower than in cultured systems (Amann et al., 1995). Various approaches to amplifying signals on the basis of an enzymic reaction have been developed (Lebaron et al., 1997; Schhuber et al., 1997). We recently reported a new fluorescent in situ hybridization technique, HNPP-FISH, using 2-hydroxy-3-naphthoic acid 2'-phenylanilide phosphate (HNPP) and Fast Red TR, which enhances the fluorescent signals eightfold compared to standard fluorescent in situ hybridization (FISH) with monoFITC-labelled oligonucleotide probes (Yamaguchi et al., 1996). In the study reported here, this technique was applied to the analysis of planktonic bacterial cells in river water.

\section{METHODS}

Organisms and culture conditions. Growth conditions and media for the organisms used in this study were as follows: Escherichia coli, $37^{\circ} \mathrm{C}$ in LB medium ( $1 \%$ tryptone, $0.5 \%$ yeast extract, $0.5 \% \mathrm{NaCl} ; \mathrm{pH} 7.0$ ); all other bacterial species, $30{ }^{\circ} \mathrm{C}$ in $\mathrm{LB}$ medium (genus Flavobacterium, $0 \% \mathrm{NaCl}$; genus Vibrio, $3 \% \mathrm{NaCl}$; all other strains, $0.5 \% \mathrm{NaCl}$ ) (Yamaguchi et al., 1996).

Sampling. River water was collected at Takayama $\left(34^{\circ} 52^{\prime}\right.$ $\left.12^{\prime \prime} \mathrm{N}, 135^{\circ} 28^{\prime} 60^{\prime \prime} \mathrm{E}\right)$ and Kitahashi $\left(34^{\circ} 41^{\prime} 27^{\prime \prime} \mathrm{N}, 135^{\circ} 32^{\prime}\right.$ $3^{\prime \prime} \mathrm{E}$ ) in northern part of Osaka, Japan (Fig. 1). Characteristics of the river water are listed in Table 1. Takayama is surrounded by forest. At this point, the river is narrow, shallow and fast-flowing. The stream bed is very rocky and the water is not exposed to domestic or industrial effluents. Kitahashi is located in a commercial area, Osaka Business Park, and considered to be highly polluted. Domestic water flows into this river upstream. Water samples were collected from the surface at each site and the physico-chemical and microbiological parameters regularly determined. The microbial community in the river water samples taken in January, April, and October of 1996 was analysed by in situ hybridization.

Oligonucleotide probes. An aligned database of $16 \mathrm{~S}$ and $23 \mathrm{~S}$ rRNA sequences was obtained from GenBank (Release 84.0). Design of oligonucleotide probes for specific bacterial groups was carried out as described previously (Yamaguchi et al., 1996). Five probes specific for different groups of Proteobacteria and the Flavobacterium-Cytophaga cluster were designed (Fig. 2, Table 2). These probes are targeted to regions of the $16 \mathrm{~S}$ rRNA characteristic for the FlavobacteriumCytophaga group (FC), the Burkholderia-Pseudomonas

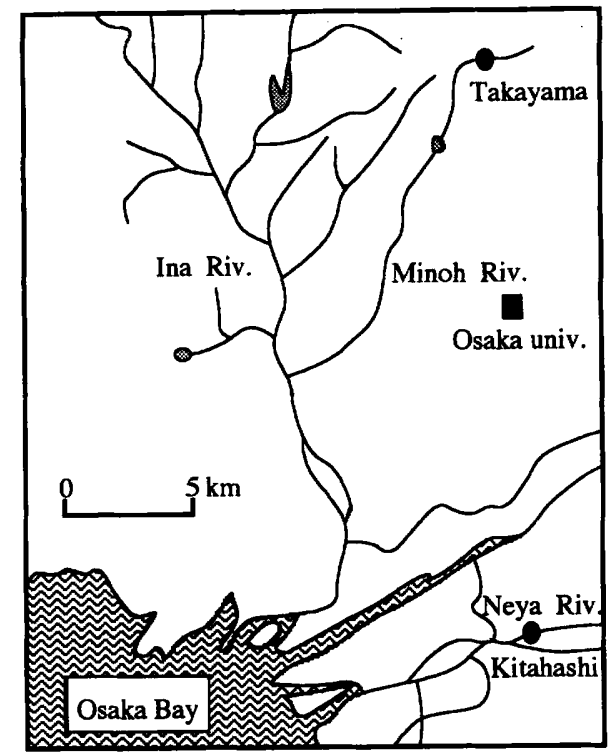

Fig. 1. Map of northern Osaka. The sampling sites are marked by black circles. Osaka University is shown as a black square. The Minoh river originates in the Minoh Mountains and joins the Ina river. Takayama is located upstream of the Minoh river. Kitahashi is located downstream of the Neya river. These rivers both flow into Osaka Bay.

(rRNA III)-authentic Alcaligenes group (BPA), the genus Acinetobacter ( $\mathrm{Ac}$ ) and the Vibrio-Aeromonas group (VA), and to regions of 23S rRNA for Pseudomonas (rRNA I) [P(I)]. Target bacteria had fewer than three mismatches with each probe. The probe EUB338, specific for the domain Bacteria (Amann et al., 1990), and the negative control probe NON338 (Wallner et al., 1993), were also used.

In situ hybridization. Paraformaldehyde (12\%, w/v, in PBS) was added to the collected samples to a final concentration of $3 \%(\mathrm{w} / \mathrm{v})$ and cells were fixed at $4{ }^{\circ} \mathrm{C}$ overnight. Cells were captured on polycarbonate filters (Millipore; pore size $0.2 \mu \mathrm{m}$ ) which were then transferred to centrifuge tubes (Iwaki Glass; volume $50 \mathrm{ml}$ ), and resuspended in $2 \mathrm{ml}$ double-distilled water. Bacterial cells from river water samples were similarly concentrated.

HNPP-FISH of river water samples was performed by a modification of the method described in our previous report (Yamaguchi et al., 1996). Twenty microlitres of fixed cell suspension was spotted onto gelatin-coated slides $[0.1 \%$ gelatin, $0.01 \% \mathrm{KCr}\left(\mathrm{SO}_{4}\right)_{2}$ ], and dried under vacuum. After dehydration in 50,80 , and $100 \%$ (v/v) ethanol (3 min each), samples were incubated with lysozyme $\left(0.5 \mathrm{mg} \mathrm{m}^{-1}\right.$ in $100 \mathrm{mM}$ Tris/ $\mathrm{HCl} \mathrm{pH} 8 \cdot 2,50 \mathrm{mM}$ EDTA) at $4{ }^{\circ} \mathrm{C}$ for $15 \mathrm{~min}$, rinsed with double-distilled water, and dehydrated as described above. Permeabilization was promoted by treatment with proteinase $\mathrm{K}$ at a final concentration of $0.1 \mu \mathrm{g} \mathrm{ml}^{-1}$ in TE buffer (10 $\mathrm{mM}$ Tris/ $\mathrm{HCl} \mathrm{pH} \mathrm{8.2,} 1 \mathrm{mM}$ EDTA) for $3 \mathrm{~min}$ at room temperature and samples were rinsed and dehydrated as described above.

The cells were hybridized in $20 \mu$ l hybridization buffer $[0.9 \mathrm{M}$ $\mathrm{NaCl}, 5 \mathrm{mM}$ EDTA, $0.1 \%$ SDS, $20 \mathrm{mM}$ Tris $/ \mathrm{HCl}$ pH 7.5, $30-45 \%(\mathrm{v} / \mathrm{v})$ formamide] containing $200 \mathrm{ng}$ digoxigeninlabelled probe at $37^{\circ} \mathrm{C}$ for $1 \mathrm{~h}$. Hybridization was terminated by sequential washes in double-distilled water at $37^{\circ} \mathrm{C}$, room 
Table 1. Physico-chemical characteristics of river water samples from the two sampling sites

\begin{tabular}{|c|c|c|}
\hline \multirow[t]{2}{*}{ Property } & \multicolumn{2}{|c|}{ Means $\pm S D$ for all $1995-96$ measurement } \\
\hline & Takayama & Kitahashi \\
\hline Ambient temp. $\left({ }^{\circ} \mathrm{C}\right)$ & $8 \cdot 3+7 \cdot 9$ & $14+9 \cdot 9$ \\
\hline Water temp. $\left({ }^{\circ} \mathrm{C}\right)$ & $8.0 \pm 5 \cdot 6$ & $16 \pm 7 \cdot 8$ \\
\hline $\mathrm{pH}$ & $7 \cdot 9 \pm 0.4$ & $7 \cdot 2 \pm 0 \cdot 4$ \\
\hline Electrical conductivity $\left(\mu \mathrm{S} \mathrm{cm}^{-1}\right)$ & $120 \pm 40$ & $470 \pm 250$ \\
\hline Total organic carbon (p.p.m.) & $2 \cdot 0 \pm 1 \cdot 3$ & $10 \pm 7 \cdot 9$ \\
\hline TDC (cells ml $\left.{ }^{-1}\right)^{*}$ & $3.0 \pm 1.7 \times 10^{5}$ & $9.9 \pm 7.7 \times 10^{6}$ \\
\hline C.f.u. (cells ml-1 $) \dagger$ & $1.3 \pm 0.8 \times 10^{4}$ & $2.5 \pm 2.6 \times 10^{6}$ \\
\hline
\end{tabular}

* Total direct counts determined by DAPI staining.

†Colony-forming units on R2A medium.

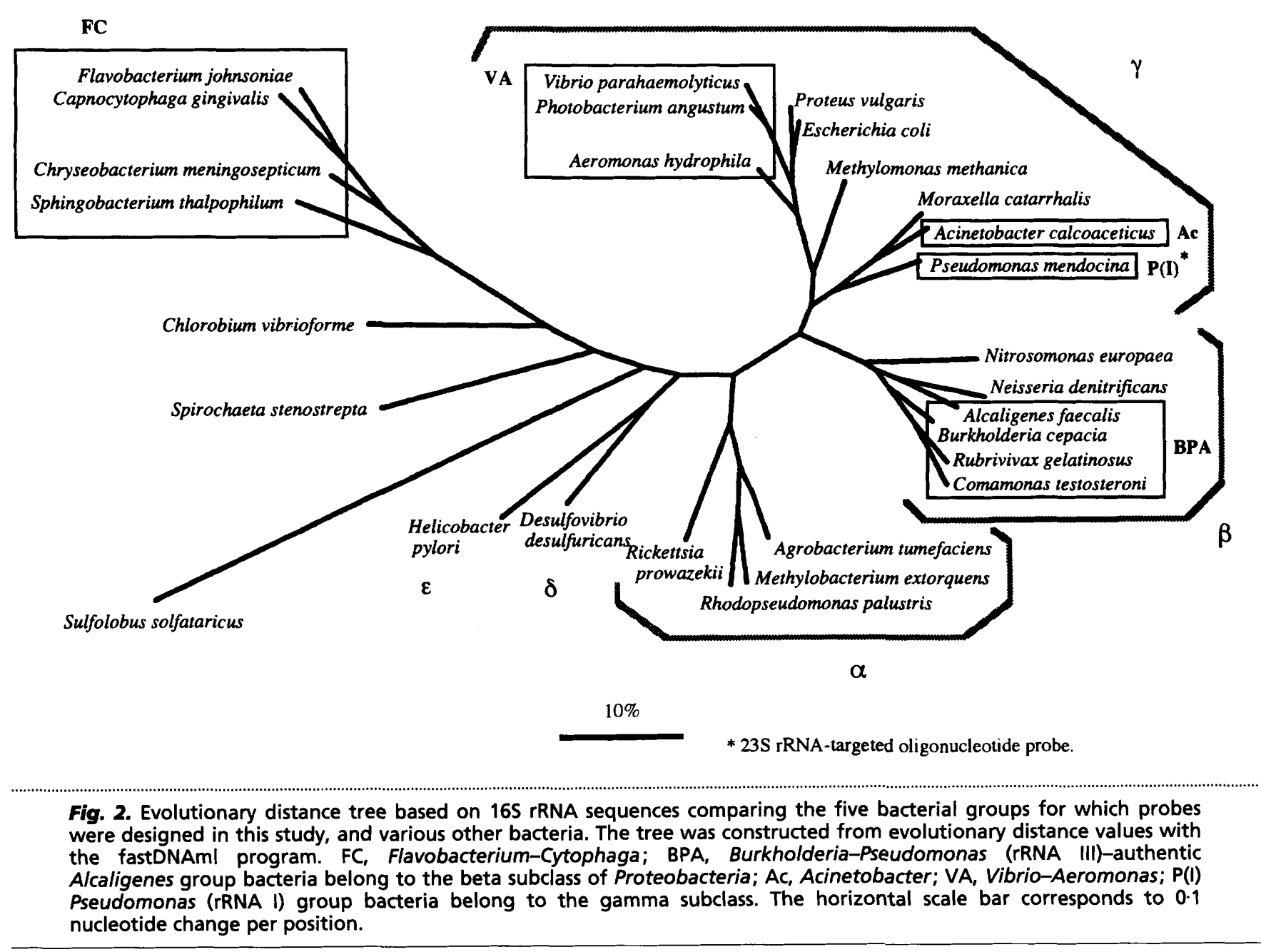

temperature and $4{ }^{\circ} \mathrm{C}$. Thirty microlitres of blocking buffer $\left[30 \mathrm{mg} \mathrm{m}^{-1}\right.$ bovine albumin (Wako Pure Chemicals Industries) in PBS] was spotted onto the preparations on ice and then incubated at room temperature for $30 \mathrm{~min}$. Fifteen microlitres of the blocking buffer was replaced by $15 \mu \mathrm{l}$ alkaline phosphatase-conjugated anti-digoxigenin $\mathrm{Fab}$ frag- ments (Boehringer) diluted 1:30 in blocking buffer (375 milliunits per sample) containing Tween 20 (final concentration $1.0 \%)$ and subsequently incubated at room temperature for $45 \mathrm{~min}$. After washing twice in buffer $1(100 \mathrm{mM}$ Tris/ $\mathrm{HCl} \mathrm{pH} \mathrm{7.5,} 150 \mathrm{mM} \mathrm{NaCl}, 0.05 \%$ Tween 20) for $10 \mathrm{~min}$, they were treated in buffer $2(100 \mathrm{mM}$ Tris $/ \mathrm{HCl}$ 
Table 2. Oligonucleotide probes designed by multiple sequence alignment

\begin{tabular}{|c|c|c|c|}
\hline $\begin{array}{l}\text { Probe } \\
\text { name }\end{array}$ & Specificity & Oligonucleotide sequence & Location \\
\hline FC & Flavobacterium-Cytophaga & 5'-AGGTA CCCCC AGCTT CCATG GCT-3' & $1408-1430^{*}$ \\
\hline BPA & $\begin{array}{l}\text { Burkbolderia-Pseudomonas } \\
\text { (rRNA III)-authentic } \\
\text { Alcaligenes }\end{array}$ & $5^{\prime}$-GTGTG CCGGT TCTCT TTCGA GCAC-3' & $1022-1044^{*}$ \\
\hline Ac & Acinetobacter & 5'-GCGCC ACTAA AGCCT CAAAG GCC-3' & $836-858^{*}$ \\
\hline VA & Vibrio-Aeromonas & 5'-ACGAC GCACT TTTTG GGATT CGCTC ACTAT CGCAA G-3' & $1265-1297^{*}$ \\
\hline $\mathbf{P}(\mathrm{I})$ & Pseudomonas (rRNA I) & $5^{\prime}$-ATTTC AGCCT ACCAC CTTAA- $3^{\prime}$ & $1467-1486+$ \\
\hline
\end{tabular}

*Homologous position on E. coli $16 \mathrm{~S}$ rRNA.

† Homologous position on E. coli $23 \mathrm{~S}$ rRNA.

$\mathrm{pH} 8 \cdot 0,100 \mathrm{mM} \mathrm{NaCl}, 10 \mathrm{mM} \mathrm{MgCl}_{2}$ ) for $10 \mathrm{~min}$ twice, and incubated in HNPP/Fast Red TR (Boehringer) solution $\left(100 \mu \mathrm{g}\right.$ HNPP ml ${ }^{-1}, 250 \mu \mathrm{g}$ Fast Red TR ml${ }^{-1}$ in buffer 2$)$ for $60 \mathrm{~min}$ at room temperature. After hybridization, complete drying was avoided, in order to limit high background signals. The samples were counter-stained with DAPI $\left(4^{\prime}, 6\right.$-diamidino2-phenylindole) after washing with double-distilled water, and mounted in Macllvaine buffer $(53.2 \mathrm{mM}$ citric acid, $93.6 \mathrm{mM} \mathrm{Na}_{2} \mathrm{HPO}_{4} \mathrm{pH} 4.5$ ) for observation by epifluorescence microscopy (BH-2; Olympus) under blue excitation (excitation filter BP490+EY455; dichroic mirror DM500; absorption filter O515) and UV excitation (excitation filter UG1; dichroic mirror DM400; absorption filter L420). For each slide, at least 3000 cells in different fields of view were counted. The microscopic enumeration results were in all cases obtained from three parallel samples with counts of more than 10000 cells.

Evaluation of probe specificity. The specificity of each designed probe was evaluated by autoradiography with 30 strains. Colony hybridization with ${ }^{32}$ P-labelled probe was performed by a modification of the method described by Berger \& Kimmel (1987). Hybridization was done at $42^{\circ} \mathrm{C}$ for $2 \mathrm{~h}$ in a solution containing $100 \mathrm{ng}$ labelled probe DNA with a specific activity of $1 \times 10^{8}$ c.p.m. $\mu \mathrm{g}^{-1}, 5 \times$ SSC, $0 \cdot 1 \%$ SDS, tenfold-diluted blocking reagent (Amersham), $0 \cdot 1 \%$ blocking component (Amersham) and $100 \mu \mathrm{g}$ denatured salmon sperm DNA $\mathrm{ml}^{-1}$. Washing for the EUB and BPA probes was at $65^{\circ} \mathrm{C}$ with $1 \mathrm{M} \mathrm{NaCl}$. Washing for the Ac probe was at $65^{\circ} \mathrm{C}$ with $0.5 \mathrm{M} \mathrm{NaCl}$. Washing for the $\mathrm{P}(\mathrm{I}), \mathrm{VA}$ and $\mathrm{FC}$ probes was at $70{ }^{\circ} \mathrm{C}$ with $1,0.5$ and $0.25 \mathrm{NaCl}$, respectively. The specificity of the designed probes was also tested with whole fixed cells of 30 strains by HNPP-FISH.

\section{RESULTS AND DISCUSSION}

\section{Specificity of the designed probes}

The target groups of the newly designed probes are shown in Fig. 2. Probe Ac is the only genus-specific probe. Pseudomonas (rRNA I) bacteria have no specific region on the $16 \mathrm{~S}$ rRNA sequence which can be discriminated from close relatives; thus the $23 \mathrm{~S}$ rRNA sequence was preferred for design of a specific probe. The specificity of the probes was evaluated by colony hybridization with the bacterial strains listed in Table 3.
Optimal washing conditions to maximize specificity for each probe were determined. Under appropriate hybridization and washing conditions, each probe bound only to the rRNAs of the predicted target strains and not to the non-target strains (data not shown).

Sensitive identification of individual bacterial cells by HNPP-FISH has been reported previously (Yamaguchi et al., 1996). In this study, fluorescent signals were enhanced and background lowered by the following improvements: (i) introduction of proteinase $\mathrm{K}$ treatment; (ii) addition of Tween 20 to the antigen/antibody reaction buffer; (iii) increase of antibody concentration in the antigen/antibody reaction. The improved method was applied to evaluate the suitability of digoxigeninlabelled probes and to analyse community structure in natural samples.

The specificity of the designed probes was tested by in situ hybridization. The stringency of hybridization was adjusted by gradually increasing (in $5 \%$ intervals) the formamide concentration in the hybridization buffer while keeping ionic strength $(0.9 \mathrm{M} \mathrm{NaCl})$ and hybridization temperature $\left(37^{\circ} \mathrm{C}\right)$ constant. Specificity and hybridization conditions with the five group-specific probes are shown in Table 3. The results show that each probe detected target bacteria even with one, two or three mismatches.

\section{Recovery rate of bacterial cells}

The change in absolute numbers of cells during the individual steps of in situ hybridization was estimated. When bacterial cells from the polycarbonate filter were resuspended, recovery of cells on to the gelatin-coated slides approached $100 \%$ in Kitahashi samples; recovery was $74-90 \%$ in Takayama samples. Neither the lysozyme nor the proteinase $\mathrm{K}$ step influenced the cell counts of samples under our conditions. The loss of bacterioplankton cells on gelatin-coated slides during all experimental steps was estimated by comparing the cell number obtained by digital images of the same microscopic fields captured by cooled CCD camera before 
Table 3. Specificity of the designed oligonucleotide probes determined by in situ hybridization

\begin{tabular}{|c|c|c|c|c|c|}
\hline \multirow[t]{2}{*}{ Strain } & \multicolumn{5}{|c|}{ Presence of signal (no. of mismatches) for probe ${ }^{*}$ : } \\
\hline & FC [23] & BPA [24] & Ac [23] & VA [36] & $\mathbf{P}(\mathrm{I})[20]$ \\
\hline $\begin{array}{l}\text { Chryseobacterium meningosepticum } \\
\text { ATCC } 13253\end{array}$ & $+(1)$ & $-(12)$ & $-(10)$ & $-(19)$ & $-(\mathrm{ND})$ \\
\hline $\begin{array}{l}\text { Flavobacterium breve (Empedobacter } \\
\text { brevis) GIFU3159 }\end{array}$ & $+(\mathrm{ND})$ & $-(\mathrm{ND})$ & $-(\mathrm{ND})$ & $-(\mathrm{ND})$ & $-(\mathrm{ND})$ \\
\hline Flavobacterium jobnsoniae ATCC 17061 & $+(2)$ & $-(7)$ & $-(12)$ & $-(12)$ & $-(\mathrm{ND})$ \\
\hline $\begin{array}{l}\text { Sphingobacterium thalpophilum ATCC } \\
43320\end{array}$ & $+(2)$ & $-(13)$ & $-(11)$ & $-(15)$ & $-(\mathrm{ND})$ \\
\hline Alcaligenes faecalis ATCC 19018 & $-(\mathrm{ND})$ & $+(\mathrm{ND})$ & $-(\mathrm{ND})$ & $-(\mathrm{ND})$ & $-(9)$ \\
\hline Alcaligenes xylosoxidans ATCC 27061 & $-(\mathrm{ND})$ & $+(\mathrm{ND})$ & $-(\mathrm{ND})$ & $-(\mathrm{ND})$ & $-(\mathrm{ND})$ \\
\hline Burkholderia cepacia ATCC 25416 & $-(9)$ & $+(1)$ & $-(8)$ & $-(13)$ & $-(10)$ \\
\hline Comamonas acidovorans IAM 12409 & $-(\mathrm{ND})$ & $+(\mathrm{ND})$ & $-(\mathrm{ND})$ & $-(\mathrm{ND})$ & $-(\mathrm{ND})$ \\
\hline Comamonas testosteroni IAM 12419 & $-(\mathrm{ND})$ & $+(\mathrm{ND})$ & $-(\mathrm{ND})$ & $-(\mathrm{ND})$ & $-(\mathrm{ND})$ \\
\hline Acinetobacter baumannii ATCC 19606 & $-(9)$ & $-(10)$ & $+(0)$ & $-(14)$ & $-(\mathrm{ND})$ \\
\hline $\begin{array}{l}\text { Acinetobacter calcoaceticus ATCC } \\
23055\end{array}$ & $-(9)$ & $-(10)$ & $+(0)$ & $-(10)$ & $-(9)$ \\
\hline $\begin{array}{l}\text { Acinetobacter haemolyticus ATCC } \\
17906\end{array}$ & $-(9)$ & $-(10)$ & $+(0)$ & $-(10)$ & $-(\mathrm{ND})$ \\
\hline Acinetobacter johnsonii ATCC 17909 & $-(9)$ & $-(10)$ & $+(0)$ & $-(10)$ & $-(\mathrm{ND})$ \\
\hline Acinetobacter junii ATCC 17908 & $-(9)$ & $-(10)$ & $+(0)$ & $-(14)$ & $-(\mathrm{ND})$ \\
\hline Acinetobacter lwoffii ATCC 15309 & $-(9)$ & $-(10)$ & $+(0)$ & $-(11)$ & $-(\mathrm{ND})$ \\
\hline Aeromonas caviae JCM 1060 & $-(10)$ & $-(11)$ & $-(12)$ & $+(2)$ & $-(\mathrm{ND})$ \\
\hline Aeromonas bydrophila ATCC 7966 & $-(9)$ & $-(13)$ & $-(11)$ & $+(2)$ & $-(10)$ \\
\hline Vibrio campbellii ATCC 25920 & $-(10)$ & $-(9)$ & $-(10)$ & $+\langle 1\rangle$ & $-(\mathrm{ND})$ \\
\hline Vibrio parahaemolyticus ATCC 17802 & $-(10)$ & $-(8)$ & $-(9)$ & $+(3)$ & $-(\mathrm{ND})$ \\
\hline Vibrio vulnificus ATCC 27562 & $-(10)$ & $-(8)$ & $-(10)$ & $+(3)$ & $-(\mathrm{ND})$ \\
\hline Pseudomonas mendocina ATCC 25411 & $-(9)$ & $-(13)$ & $-(7)$ & $-(14)$ & $+(\mathrm{ND})$ \\
\hline $\begin{array}{l}\text { Pseudomonas fluorescens RIMD } \\
1615005\end{array}$ & $-(\mathrm{ND})$ & $-(\mathrm{ND})$ & $-(\mathrm{ND})$ & $-(\mathrm{ND})$ & $+(\mathrm{ND})$ \\
\hline Pseudomonas putida ATCC 12633 & $-(9)$ & $-(10)$ & $-(6)$ & $-(15)$ & $+\langle\mathrm{ND}\rangle$ \\
\hline $\begin{array}{l}\text { Alcaligenes eutrophus (Ralstonia } \\
\text { eutropha) IAM } 12305\end{array}$ & $-(\mathrm{ND})$ & $-(\mathrm{ND})$ & $-(\mathrm{ND})$ & $-(\mathrm{ND})$ & $-(\mathrm{ND})$ \\
\hline Escherichia coli K-12 W3110 & $-(12)$ & $-(11)$ & $-(11)$ & $-(8)$ & $-(6)$ \\
\hline Moraxella bovis IAM 12313 & $-(\mathrm{ND})$ & $-(\mathrm{ND})$ & $-(\mathrm{ND})$ & $-(\mathrm{ND})$ & $-(\mathrm{ND})$ \\
\hline Moraxella lacunata IAM 12150 & $-(\mathrm{ND})$ & $-(\mathrm{ND})$ & $-(\mathrm{ND})$ & $-(\mathrm{ND})$ & $-(\mathrm{ND})$ \\
\hline Moraxella nonliquefaciens IAM 12314 & $-(\mathrm{ND})$ & $-(\mathrm{ND})$ & $-(\mathrm{ND})$ & $-(\mathrm{ND})$ & $-(\mathrm{ND})$ \\
\hline $\begin{array}{l}\text { Pseudomonas (Breviundimonas) } \\
\text { diminuta GIFU657 }\end{array}$ & $-(\mathrm{ND})$ & $-(\mathrm{ND})$ & $-(\mathrm{ND})$ & $-(\mathrm{ND})$ & $-(\mathrm{ND})$ \\
\hline $\begin{array}{l}\text { Xanthomonas (Stenotrophomonas) } \\
\text { maltophilia KM } 1168\end{array}$ & $-(\mathrm{ND})$ & $-(\mathrm{ND})$ & $-(\mathrm{ND})$ & $-(\mathrm{ND})$ & $-(\mathrm{ND})$ \\
\hline Formamide concn $(\%)$ & 30 & 40 & 40 & 45 & 45 \\
\hline
\end{tabular}

*Probe lengths are shown in square brackets (see also Table 2). ND, No data: sequence data are not available in GenBank.

enzymic treatment and after all procedures. More than $90 \%$ of the DAPI-stained cells remained on the slide.

\section{Bacterial community structure}

In the samples from Kitahashi (the eutrophic site), the percentages of DAPI-stained cells that could be visualized microscopically with EUB338 were $68 \pm 2 \%$
(29 Jan), $59 \pm 5 \%(18 \mathrm{Apr})$ and $54 \pm 1 \%(1 \mathrm{Oct})$. In the sample from Takayama (the oligotrophic site) the percentages were $45 \pm 3 \%$ (29 Jan), $40 \pm 3 \%$ (18 Apr) and $39 \pm 1 \%$ (9 Oct) of all DAPI-stained cells hybridized with EUB338 (Fig. 3). The counts with the negative control probe (NON338) accounted for less than $0.5 \%$ of the DAPI counts in both samples. The visualization of resident bacteria hybridizing with EUB338 is shown in 


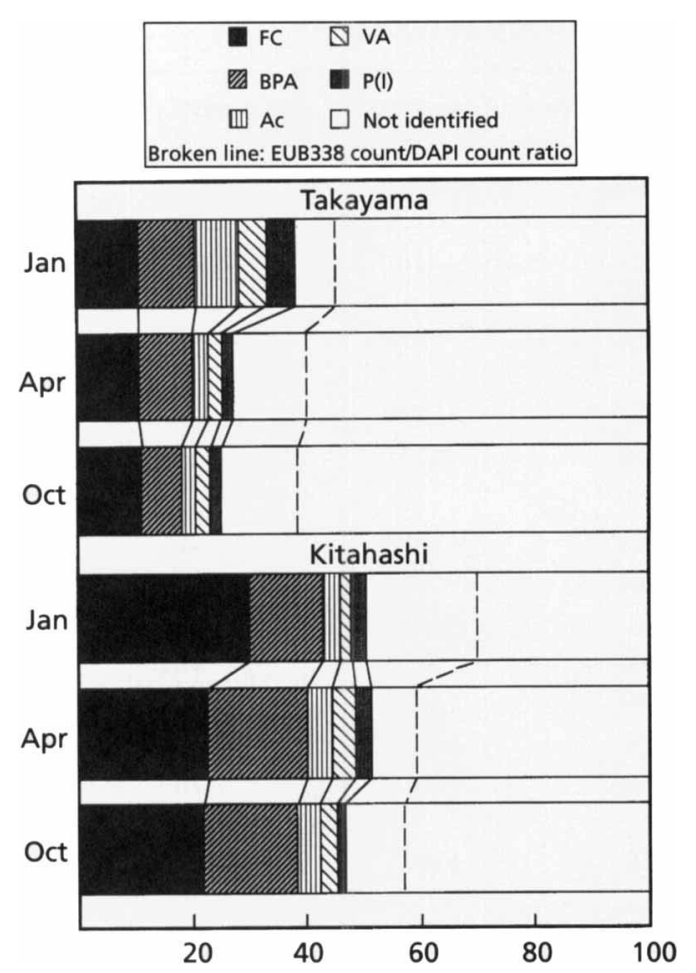

Fig. 3. Comparison of microbial community structure in river water samples collected at Takayama (oligotrophic site) and Kitahashi (eutrophic site) in winter, spring and autumn of 1996. See Table 2 for probe specificities.

Fig. 4. The bright orange staining of bacteria facilitated reliable enumeration (Fig. 4a, c). Counterstaining hybridized cells with DAPI allowed enumeration within the same preparation of both the total number of bacterial cells and the cells that were detected by a given probe (Fig. 4b, d).

Definitive studies correlating environmental conditions with microbial community composition in natural samples are difficult because, until recently, few methods have been available for identifying and quantifying specific bacteria or bacterial groups in the environment without cultivation. In the present study, HNPP-FISH, which we recently used for the sensitive identification of cultured cells (Yamaguchi et al., 1996), was applied successfully to the analysis of complex microbial communities in natural river water with differing levels of pollution. Application of standard FISH with monoFITC-labelled oligonucleotide probes to river water samples from Kitahashi was less successful; fewer than $20 \%$ of all DAPI-stained cells were positive with EUB338 (data not shown). Sensitive in situ hybridization with HNPP/Fast Red TR, as employed here, amplifies the fluorescent signal of hybridized bacterial cells by an enzymic reaction. Recently, hybridization with Cy3labelled oligonucleotide probes in the natural aquatic environment has been reported (Alfreider et al., 1996; Glöckner et al., 1996) to give detection yields in a similar range to those reported here.

Interestingly, the percentage of total bacteria detectable with EUB338 differed at Kitahashi (the eutrophic site) and Takayama (the oligotrophic site). This is probably due to differences in the abundance of bacteria with enough rRNA for detection. The general metabolic activity of bacterioplankton is presumably higher in a eutrophic environment. For example, Kirchman et al. (1985) demonstrated that levels of uptake of radioisotope-labelled substrates as an index of protein synthesis were higher at sites where the micro-organisms were exposed to higher levels of pollutants, and we found that estimates of physiologically active bacteria in eutrophic rivers were higher than those in oligotrophic rivers (Yamaguchi et al.,1997). At eutrophic sites, bacteria may be growing faster and have a higher rRNA content.

Hybridization with the five group-specific probes resulted in straightforward detection of stained individual cells. Group-specific probe counts for both samples are given as the percentage of DAPI-stained cells in Fig. 3. In the sample from Kitahashi on 29 January, FC (30 $13 \%)$ and BPA $(13 \pm 1 \%)$ counts predominated over Ac $(3 \pm 0.5 \%)$, VA $(2 \pm 0.5 \%)$ and $P(I)(2 \pm 1 \%)$ counts. The community structure did not change appreciably at other sample dates (Fig. 3). Community composition in the sample from Takayama on 25 January was $11 \pm 3 \%$ FC, $10 \pm 1 \%$ BPA, $8 \pm 2 \%$ Ac, $5 \pm 2 \%$ VA and $5 \pm 0.5 \%$ $\mathrm{P}(\mathrm{I})$. Similar results were obtained from the samples of 18 April and 9 October (Fig. 3).

The thorough analysis of microbial community structures requires hybridization with nucleic acid probes for specific populations in the environment of interest. Wagner et al. (1994) applied oligonucleotide probes specific for the genus Acinetobacter for in situ monitoring in activated sludge. Ramsing et al. $(1993,1996)$ used specific probes for sulfate-reducing bacteria to help elucidate the role of the bacteria in the environment. In the present study, five specific probes for certain bacterial groups that are often reported to exist in the natural aquatic environment were designed and employed to analyse microbial community structure in river water. The sum of all bacteria classified by these probes was more than $50 \%$ of the DAPI-stained cells in the sample from Kitahashi and $25-38 \%$ from Takayama. Most of the EUB338-detectable cells could be identified with the five group-specific probes (Fig. 3). The oligonucleotide probes in this study thus provide a substantial amount of information on bacterial community structure in the river water ecosystem. We believe that this study is the first to closely examine the community composition of the bacteria in river water. Rivers are important ecosystems but the characterization of their indigenous bacterial populations has been comparatively neglected.

Many researchers have investigated the taxonomic distribution and seasonal fluctuation of bacterial strains 

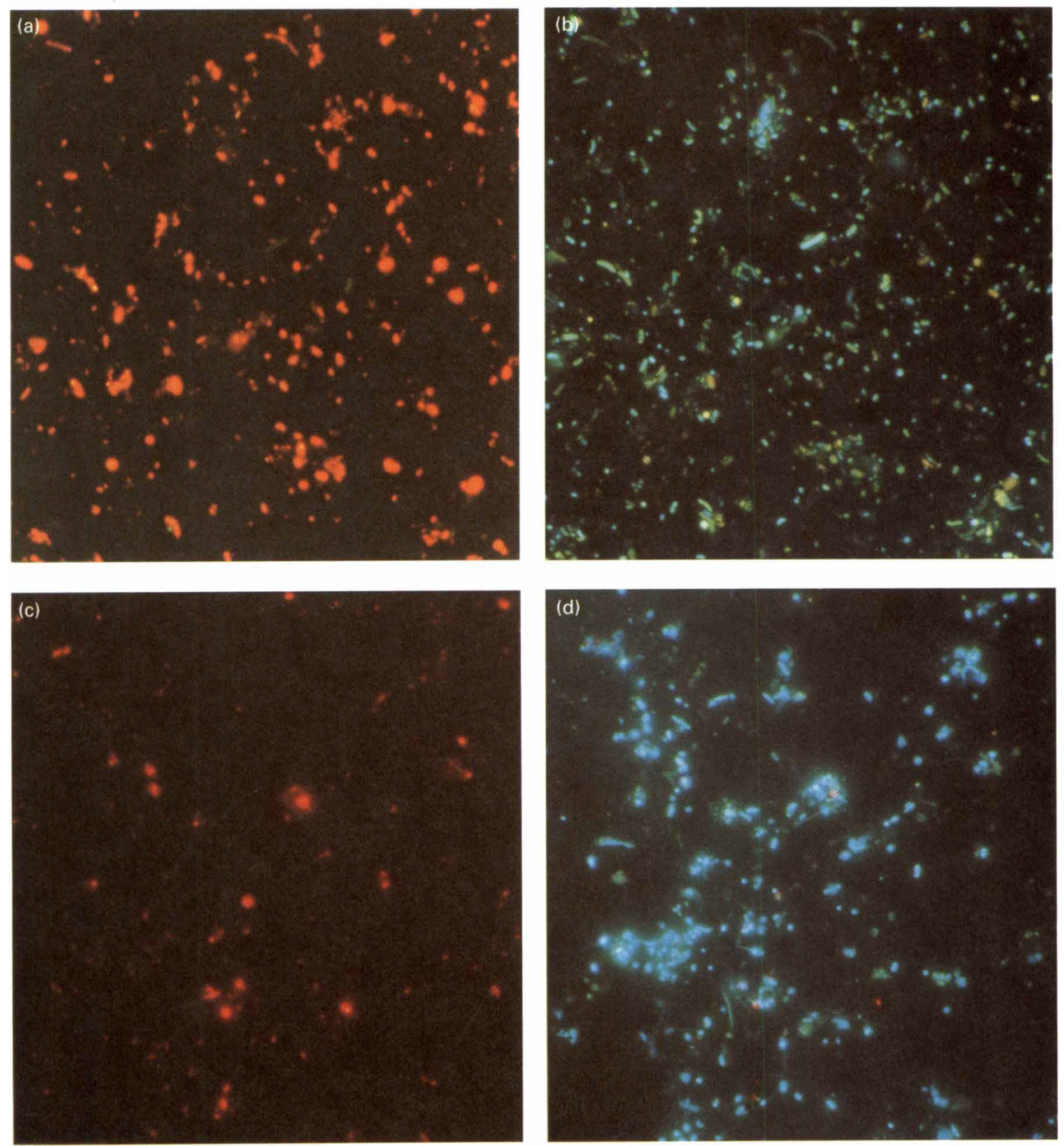

Fig. 4. Typical micrographs of bacterial cells detected by HNPP/Fast Red TR whole-cell hybridization: cells hybridized with EUB338 in river water samples collected from Kitahashi $(a, b)$ and Takayama $(c, d)$. Only bacteria detected by the probe showed the orange fluorescence of HNP/TR under blue excitation. The same microscopic fields are shown with UV excitation ( $b, d)$ and Blue excitation ( $a, c)$. Magnification $\times 850$.

in natural aquatic systems on the basis of culturedependent methods. A predominance of Flavobacterium in river and lake samples has been reported in several studies (Lighthart, 1975; Konda \& Tezuka, 1979; Maeda, 1980; Stopinski, 1981; Nuttall, 1982; Sugita et al., 1982; Flint, 1985). The detection of Flavobacterium as a predominant genus is consistent with our results: Flavobacterium-Cytophaga (FC) group bacteria dominated the bacterial community at both sites throughout the sampling period. FC-group bacteria may be common in freshwater systems, and sometimes constitute a considerable cell fraction. Analysis of the physiology of members of the predominant genera will increase our understanding of their roles in nature, and studies combining modern molecular and traditional cultivation-based techniques should give new insights into the ecology of rivers.

This study demonstrated the feasibility of HNPP-FISH analysis of environmental samples with group-specific oligonucleotide probes. However, $30-40 \%$ of the DAPIstained cells in the sample from Kitahashi, and approxi- 
mately $60 \%$ in the sample from Takayama, still could not be identified by HNPP/Fast Red TR whole-cell hybridization with EUB338. These cells may have been impermeable to probes or anti-digoxigenin Fab fragments conjugated to alkaline phosphatase ( $>244 \mathrm{kDa})$, or perhaps did not have a ribosomal content high enough for detection by this technique. Cells which are impermeable to probes or antibody, may be resistant to lysozyme or proteinase $\mathrm{K}$ treatment. Certain Grampositive bacteria, e.g. Staphylococcus spp., were not sensitive to these enzymes under our conditions. The application of other enzymic or chemical treatments may be required for in situ identification of such bacteria, and the detection of larger phylogenetic entities remains limited even with an improved HNPP/Fast Red TR system because cell wall structure and thus probe accessibility may differ between individual species.

Cells with low metabolic activity may be detected by in situ PCR. Hodson et al. (1995) successfully applied this technique to bacteria and demonstrated that prokaryotic in situ PCR enabled single cells within complex mixtures to be not only identified but also characterized genetically. The combination of an HNPP/Fast Red TR detection system with prokaryotic in situ PCR could provide information about specific genes and their transcripts at the single-cell level (Kurokawa et al., 1997). Moreover, the sensitivity of the in situ PCR technique could be further improved by employing highsensitivity optical instruments such as the cooled CCD camera (Ramsing et al., 1996).

\section{REFERENCES}

Alfreider, A., Pernthaler, J., Amann, R., Sattler, B., Glöckner, F. O., Wille, A. \& Psenner, R. (1996). Community analysis of the bacterial assemblages in the winter cover and pelagic layers of a high mountain lake by in situ hybridization. Appl Environ Microbiol 62, 2138-2144.

Amann, R. I., Binder, B. J., Olson, R. J., Chisholm, S. W., Devereux, R. \& Stahl, D. A. (1990). Combination of $16 \mathrm{~S}$ rRNA-targeted oligonucleotide probes with flow cytometry for analyzing mixed microbial populations. Appl Environ Microbiol 56, 1919-1925.

Amann, R. I., Ludwig, W. \& Schleifer, K.-H. (1995). Phylogenetic identification and in situ detection of individual microbial cells without cultivation. Microbiol Rev 59, 143-169.

Belser, L. W. (1979). Population ecology of nitrifying bacteria. Annu Rev Microbiol 33, 309-333.

Berger, S. L. \& Kimmel, A. R. (1987). Guide to molecular cloning techniques. In Screening Colonies or Plaques with Radioactive Nucleic Acid Probes, pp. 415-423. Edited by G. M. Wahl \& S. L. Berger. New York: Academic Press.

Flint, K. P. (1985). A note on a selective agar medium for the enumeration of Flavobacterium species in water. J Appl Bacteriol 59, 561-566.

Giovannoni, S. J., Britschgi, T. B., Moyer, C. L. \& Field, K. G. (1990). Genetic diversity in Sargasso Sea bacterioplankton. Nature 345, 60-63.

Glöckner, F. O., Amann, R., Alfleider, A., Pernthaler, L., Psenner, R., Trebesius, K. \& Field, K. G. (1996). An in situ hybridization protocol for detection and identification of planktonic bacteria. Syst Appl Microbiol 19, 403-406.
Hicks, R. E., Amann, R. I. \& Stahl, D. A. (1992). Dual staining of natural bacterioplankton with 4',6-diamidino-2-phenylindole and fluorescent oligonucleotide probes targeting kingdom-level $16 \mathrm{~S}$ rRNA sequences. Appl Environ Microbiol 58, 2158-2163.

Hodson, R. E., Dustwan, W. A., Garg, R. P. \& Moran, M. A. (1995). In situ PCR for visualization of microscale distribution of specific genes and gene products in prokaryotic communities. Appl Environ Microbiol 61, 4074-4082.

Kirchman, D., K'nees, E. \& Hodson, R. (1985). Leucine incorporation and its potential as a measure of protein synthesis by bacteria in natural aquatic systems. Appl Environ Microbiol 49, 599-607.

Kogure, K., Simidu, U. \& Taga, T. (1979). A tentative direct microscopic method for counting living marine bacteria. Can $J$ Microbiol 25, 415-420.

Konda, T. \& Tezuka, Y. (1979). Bacterial flora in the water and sediment of lake Motosu-ko, an oligotrophic lake in central Japan. Jpn J Ecol 29, 209-220.

Kurokawa, K., Tani, K. \& Nasu, M. (1997). Direct in situ PCR method for the detection of verotoxin-producing Escherichia coli. Jpn J Bacteriol 52, 513-518.

Lebaron, P., Catala, P., Fajon, C., Joux, F., Baudart, J. \& Bernard, L. (1997). A new sensitive, whole-cell hybridization technique for detection of bacteria involving a biotinylated oligonucleotide probe targeting rRNA and tyramide signal amplification. Appl Environ Microbiol 63, 3274-3278.

Lighthart, B. (1975). A cluster analysis of some bacteria in the water column of Green Lake, Washington. Can J Microbiol 21, 392-394.

Lovley, D. R. (1991). Dissimilatory Fe(III) and $\mathrm{Mn}$ (IV) reduction. Microbiol Rev 55, 259-287.

Maeda, S. (1980). The flora of aerobic heterotrophic bacteria in the river Sagami. Jpn J Limnol 41, 163-171.

Nuttall, D. (1982). The populations, characterization and activity of suspended bacteria in the Welsh River Dee. J Appl Bacteriol 53, 49-59.

Olsen, R. A. \& Bakken, L. R. (1987). Viability of soil bacteria, optimization of plate-counting technique and comparison between total counts and plate counts within different size groups. Microb Ecol 13, 59-74.

Peele, E. R., Singleton, F. L., Deming, J. W., Cavari, B. \& Colwell, R. R. (1981). Effects of pharmaceutical wastes on microbial populations in surface waters at the Puerto Rico dump site in the Atlantic Ocean. Appl Environ Microbiol 41, 873-879.

Ramsing, N. B., Kühl, M. \& Jørgensen, B. B. (1993). Distribution of sulfate-reducing bacteria, $\mathrm{O}_{2}$ and $\mathrm{H}_{2} \mathrm{~S}$ in photosynthetic biofilms determined by oligonucleotide probes and microelectrodes. Appl Environ Microbiol 59, 3840-3849.

Ramsing, N. B., Fossing, H., Ferdelman, T. G., Andersen, F. \& Thamdrup, B. (1996). Distribution of bacterial populations in a stratified Fjord (Mariager Fjord, Denmark) quantified by in situ hybridization and related to chemical gradients in the water column. Appl Environ Microbiol 62, 1391-1404.

Schhuber, W., Fuchs, B., Juretschko, S. \& Amann, R. (1997). Improved sensitivity of whole-cell hybridization by the combination of horseradish peroxidase-labeled oligonucleotides and tyramide signal amplification. Appl Environ Microbiol 63, 3268-3273.

Stahl, D. A., Lane, D. J., Olsen, G. J. \& Pace, N. R. (1985). Characterization of a Yellowstone hot spring microbial community by $5 S$ rRNA sequences. Appl Environ Microbiol 45, 1379-1384. 
Stopinski, M. (1981). Studies on psychrophilic bacteria in two lakes of different trophy. Acta Microbiol Pol 30, 283-294.

Sugita, H., Tanaami, H., Kobashi, T. \& Deguchi, Y. (1982). Bacterial flora of the water and sediment in the Edo river mouth. Jpn J Limnol 43, 27-34.

Suzuki, M. T. \& Giovannoni, S. J. (1996). Bias caused by template annealing in the amplification of mixtures of $16 \mathrm{~S}$ rRNA genes by PCR. Appl Environ Microbiol 62, 625-630.

Teske, A., Wawer, C., Muyzer, G. \& Ramsing, N. B. (1996). Distribution of sulfate-reducing bacteria in a stratified Fjord (Mariager Fjord, Denmark) as evaluated by most-probablenumber counts and denaturing gradient gel electrophoresis of PCR-amplified ribosomal DNA fragments. Appl Environ Microbiol 62, 1405-1415.

Torsvik, V., Salte, K., Sørheim, R. \& Goksøyr, J. (1990). Comparison of phenotypic diversity and DNA heterogeneity in a population of soil bacteria. Appl Environ Microbiol 56, 776-781.

Wagner, M., Erhart, R., Manz, W., Amann, R., Lemmer, H., Wedi, D. \& Schleifer, K. H. (1994). Development of an rRNA-targeted oligonucleotide probe specific for the genus Acinetobacter and its application for in situ monitoring in activated sludge. Appl Environ Microbiol 60, 792-800.
Wallner, G., Amann, R. I. \& Beisker, W. (1993). Optimizing fluorescent in situ hybridization with rRNA-targeted oligonucleotide probes for flow cytometric identification of microorganisms. Cytometry 14, 136-143.

Wallner, G., Erhart, R. \& Amann, R. (1995). Flow cytometric analysis of activated sludge with rRNA-targeted probes. Appl Environ Microbiol 61, 1859-1866.

Weisburg, W. G., Barns, S. M., Pelletier, D. A. \& Lane, D. J. (1991). $16 \mathrm{~S}$ ribosomal DNA amplification for phylogenetic study. $J$ Bacteriol 173, 697-703.

Wolin, M. J. \& Miller, T. L. (1987). Bioconversion of organic carbon to $\mathrm{CH}_{4}$ and $\mathrm{CO}_{2}$. Geomicrobiol J 5, 239-260.

Yamaguchi, N., Inaoka, S., Tani, K., Kenzaka, T. \& Nasu, M. (1996). Detection of specific bacterial cells with 2-hydroxy-3-naphthoic acid-2'-phenylanilide phosphate and Fast Red TR in situ hybridization. Appl Environ Microbiol 62, 275-278.

Yamaguchi, N., Kenzaka, T. \& Nasu, M. (1997). Rapid in situ enumeration of physiologically active bacteria in river waters using fluorescent probes. Microb Environ 12, 1-8.

Received 10 November 1997; revised 27 March 1998; accepted 28 April 1998. 